Rok XVI (2021) | 1 (31) | S. 199-209

https://doi.org/10.12797/LV.16.2021.31.15

Licencja: CC BY-NC-ND 4.0

Maciej Mączyński ๑

Uniwersytet Pedagogiczny im. Komisji Edukacji Narodowej w Krakowie

maciej.maczynski@up.krakow.pl

\title{
GWAROWE NAZWY KOBIET Z SUFIKSEM -ULA
}

Słowa klucze: sufiks -ula, gwary, nazwy kobiet, ekspresywność języka

Keywords: suffix -ula, dialects, female names, language expressiveness

Przedmiotem analizy w artykule są apelatywy osobowe, zazwyczaj nacechowane emocjonalnie, rozumiane jako „rzeczowniki pospolite używane na oznaczenie ludzi, posiadające zdolność określania wielu desygnatów i niosące z sobą obligatoryjnie poza semantycznymi - treści emocjonalne" (Piechnik 2009: 10). Materiał leksykalny poddany badaniu pochodzi z kartoteki SGP PAN. Oczywiście można sądzić, iż poza kartoteką pozostał szereg wyrazów utworzonych sufiksem -ula wchodzących w skład interesującego mnie pola wyrazowego, traktuję jednak kartotekę jako największy zbiór słownictwa gwarowego pozwalający na dokonywanie uogólnień (myślę, że z racji wycofywania się gwar większym zbiorem dysponować już nie będziemy). Z kartoteki wynotowałem 138 derywatów utworzonych sufiksem -ula będących apelatywnymi nazwami kobiet utworzonymi od różnych podstaw słowotwórczych. Do badanego pola włączyłem te wyrazy, które w definicji leksykalnej zawierały komponent 'kobieta' (również 'dziewczyna', 'dziewczynka'), włączyłem też wyrazy, które takiego komponentu nie miały, ale w ich definicjach albo użyto komponentu 'człowiek' (z dodatkowych objaśnień na fiszce wynikało, iż wyraz może nazywać kobietę), albo zaznaczono wyraźnie, że nazwa odnosi się zarówno do mężczyzn, jak i do kobiet, co w kartotece symbolizowały skróty $m$ i ż.

Badania formacji z sufiksem -ula mają swoją historię. Już w roku 1929 Witold Doroszewski (1929: 81) pisał: „Z sufiksów -ul, -ula produktywniejszy jest na gruncie ogólno-słowiańskim sufiks rodzaju żeńskiego, w języku polskim -ul prawie nie- 
znane [...]". Sufiks -ula tworzył zdrobnienia od imion typu Kasia - Kasiula, apelatywy matula, babula, kozula oraz nazwy krów Krasula, Siwula. Z funkcją deminutywną sufiksu Doroszewski wiązał też tworzenie nazw osób płci żeńskiej od nazw męskich typu Sikorula 'żona Sikory’. O tych ostatnich formacjach pisał Alfred Zaręba (1965). Badając przyrostki tworzące formy żeńskie od nazwisk (także przydomków i imion) męża, Zaręba poddał szczegółowej analizie formacje z sufiksem -ula typu Gmyra - Gmyrula, wyznaczył ścisły zasięg tego formantu oraz ustalił jego genezę i funkcje. Stwierdził mianowicie, że -ula to formant ogólnosłowiański „o podstawowym znaczeniu feminizującym (z zabarwieniem zdrabniającym). Z tego znaczenia wytworzyło się później wtórne, zawężone do [...] kategorii odmężowskiej" (ibid.: 462). Badacz zwrócił także uwagę na formacje typu krawcula, szewcula, w których sufiks tworzy nazwy kobiet od nazw zawodów mężów, oraz na formacje odapelatywne nazywające kobiety w ogóle typu chlaptula, pyskula. Stefan Warchoł w roku 1968 stwierdził, że w słowiańskich nazwach osobowych i apelatywach sufiks -ula ma funkcję przede wszystkim ekspresywną. W polszczyźnie np. tworzy różnego rodzaju odapelatywne nazwy o zabarwieniu pejoratywnym, nazwy żon od nazwisk mężów, także nazwy córek od nazwisk ojców, a w Małopolsce nazwy krów typu Krasula, Rogula. Mniej licznie natomiast tworzy nazwy roślin i narzędzi (Warchoł 1968: 57). Omawiając szczególną produktywność pewnych typów słowotwórczych, Władysław Cyran (1977: 56) wymienił nazwy pomniejszające, wśród których zanotował 11 gwarowych formacji z sufiksem -ula. Były to wyrazy: babula, ciotula, córula, dziewula, gębula, kieszula (od kieszeń), kozula, krowula, mamula, matula, wdowula. Gwarowe formacje z sufiksem -ula wyekscerpowane z kartoteki SGP PAN omówiła Anna Kowalska (1982). Około 200 wyrazów gwarowych - głównie apelatywów - autorka sklasyfikowała, przyjmując za podstawę podziału charakter gramatyczny podstaw słowotwórczych (verbum, adiectivum, substantivum). W obrębie tak wyróżnionych grup zastosowała kryterium semantyczne pozwalające na pogrupowanie derywatów według kategorii słowotwórczych (np. nomina agentis, nomina attributiva, deminutiva). We wnioskach, oprócz procentowych wyliczeń dotyczących udziału poszczególnych części mowy w tworzeniu formacji z sufiksem -ula, autorka zawarła kilka istotnych spostrzeżeń: 1) sufiks -ula pełni funkcję ogólnie feminizującą, 2) w formacjach apelatywnych najważniejszą funkcją tego formantu jest funkcja ekspresywna, 3) tworzy deminutywa, hipokorystyka oraz formacje o zabarwieniu pejoratywnym (ibid.: 75). W innych pracach sufiks -ula jest omawiany jako jeden ze środków językowych tworzących pejoratywne nazwy osób (Masłowska 1980; Kobylińska 2003) bądź formacje o zabarwieniu dodatnim (Janiga 2016: 89).

W słownikach polszczyzny ogólnej formacje z sufiksem -ula są zdecydowanie rzadsze. SStp formantu nie notuje. W SPXVI zanotowano 39 wyrazów z cząstką -ula, ale są to najczęściej zapożyczenia (np. nazwy roślin) bądź wyrazy, w których -ula nie jest formantem. W elektronicznym Słowniku języka polskiego XVII i XVIII wieku (SJP XVII i XVIII) zanotowano 23 wyrazy kończące się na -ula, z czego tylko ze- 
zula ma interesujący nas sufiks. W SL mamy 26 wyrazów zakończonych na -ula, w tym tylko w 8 można wyodrębnić sufiks -ula. Należą tu wyrazy wyraźnie nacechowane ekspresywnością, będące formacjami hipokorystycznymi: babula, ciotula, kozula, matula, wdowula, żonula, żorula ${ }^{1}$. Derywat damula jako jedyny komunikuje pogardliwy stosunek mówiącego do obiektu. W SJPD zamieszczono 17 formacji z sufiksem -ula. 12 derywatów to formacje odrzeczownikowe nacechowane ekspresywnością, np. ciotula, córula, matula, 2 to derywaty odczasownikowe: wrzaskula, zgadula, 2 odprzymiotnikowe: biedula, brzydula i 1 dwumotywacyjny: smarkula (Grzegorczykowa, Puzynina 1979: 219) ${ }^{2}$. Z powyższego przeglądu wynika, że sufiks -ula charakteryzował się o wiele większą produktywnością w gwarach niż w języku ogólnym.

Materiał pozyskany z kartoteki SGP PAN podzieliłem na 5 grup przedstawionych niżej³ . O przynależności do grupy decydowało znaczenie wyrazu. Dla każdej nazwy próbowałem ustalić podstawę słowotwórczą (rozumianą jako wyraz podstawowy), którą w większości była nazwa męska ${ }^{4}$. Lokalizację wyrazów podałem nie za kartoteką SGP PAN, lecz zgodnie z propozycją Renaty Kucharzyk (2015: 171) zastosowałem lokalizację uogólnioną. Na taki zabieg pozwolił mi - jak sądzę - fakt, że celem badań nie było wyznaczenie ścisłej izomorfy sufiksu -ula, lecz tylko ogólne zorientowanie się, na jakim terenie jest on produktywny.

\section{Nazwy kobiet mówiących dużo, niepotrzebnie (mówić co):}

bajdula 'kobieta lubiąca dużo mówić, niepotrzebnie, powtarzać zasłyszane wieści' (Młp pd) od bajdak 'człowiek mało rozgarnięty, plotący głupstwa'; bejdula 'kobieta mówiąca bez sensu, pleciuga' (Młp pd) od bejdak 'ts.; bebłula (m i ż) 'człowiek,

1 O tym ostatnim wyrazie W. Doroszewski (1929: 81) pisze: „Osobliwą formacją jest żorula 'biedna żórawiczka' (L) utworzona z pominięciem sufiksu -aw”.

2 Autorki opracowania wskazują możliwą motywację derywatu smarkula wyrazami smarkata lub smarkać. Wydaje się jednak, że wyraz pochodzi od nazwy męskiej smarkacz 'niedorosły chłopiec'.

3 Z konieczności materiał przedstawiam w wyborze.

4 O pochodzeniu nazw żeńskich od męskich pisał Bogusław Kreja (1964: 129): „Kategoria słowotwórcza nazw żeńskich jest kategorią wyraźnie zarysowaną. Należą do niej wszystkie feminatywa, czyli nazwy żeńskie utworzone od odpowiednich nazw męskoosobowych przy pomocy właściwych formantów słowotwórczych. Formant feminatywny wnosi do tego rodzaju nazwy jedynie cechę żeńskości, a znaczenie zasadnicze (zawodu, czynności, cechy itd.) wzięte jest z podstawowej nazwy męskiej". W Gramatyce współczesnego języka polskiego (Grzegorczykowa, Puzynina 1984: 364) nazwy żeńskie zaliczono również do formacji modyfikacyjnych, przyjmując, iż są one motywowane nazwami męskimi. Autorki opracowania zwracają jednak uwagę na zjawisko podwójnej motywacji - rzeczownikiem lub czasownikiem.

W artykule przyjąłem, iż część nazw żeńskich pochodzi od poświadczonych w kartotece SGP PAN nazw męskich. Mam wszakże świadomość możliwej podwójnej motywacji rzeczownikiem i czasownikiem lub inną częścią mowy. 
który dużo i beztreściwie mówi, gaduła, pleciuga' (Opol) od bebłak/bebłacz 'mówiący prędko, niezrozumiale'; blajdula 'kobieta mówiąca niemądrze', 'plotkara' (Młp pd) od blajdak 'człowiek mówiący niemądrze, plotący głupstwa'; chlaptula 'kobieta gadatliwa, pleciuga, plotkara' (Młp pd, Ciesz) od chlaptak 'taki, co głupio mówi'; chlastula 'kobieta, która mówi niemądrze' (Młp pd, Opol) od chlastacz 'pyskacz, człowiek wygadany' albo chlastak 'plotkarz'; drzystula 'o kobiecie, która dużo i głupio mówi' (Młp pd, Śl pd-zach, Ciesz) od drzystak 'człowiek mówiący dużo i głupio'; fyrtula 'o kobiecie: gaduła' (Ciesz) od fyrtak 'człowiek prędki' ze zmianą znaczenia; gadula 'gaduła' (Młp pn-zach), 'gadatliwa kobieta', niekiedy też o mężczyźnie 'człowiek gadatliwy, plotkarz' (Opol) od gadać; klachula 'plotkara' (Ciesz, Opol) od klachak 'ts.'; krzęczula 'kobieta, która dużo mówi' (Młp pd) od krzęk 'człowiek gderliwy, gaduła'; pletkula 'plotkarka' (Opol) od pletkarz 'plotkarz'; plotkula 'plotkarka' (Śl pd-zach, Opol) od plotkarz; rajcula 'lubiąca dużo mówić, popisywać się' (Młp wsch i pd-zach, Śl pd-zach) od rajca 'człowiek, który dużo mówi; wygadany, lubiący się popisywać; szczekula 'kobieta pyskata' (Ciesz) od szczekacz 'człowiek wygadany, mówca'; terkula/tyrkula 'plotkarka' (Śl pd-zach) od terczeć/terkać 'mielić ozorem, plotkować; tertula 'człowiek, który dużo mówi, gaduła', 'plotkarka' (Śl pd-zach, Opol) od tertać 'terczeć, terkotać; być niedyskretnym'; tryńdula 'kobieta mówiąca do znudzenia, plotkarka' (Ciesz) od tryńdać 'mówić pod nosem’.

\section{Nazwy kobiet mówiących w jakiś sposób (mówićjak):}

ciamkula 'kobieta mówiąca niewyraźnie' (Młp pd) od ciamkacz 'ts.'; mamrula 'kobieta mówiąca grubym głosem' (Młp śr) od mamracz 'ts.'; mruczula/murcula 'kobieta, która mruczy' (Młp pd) od mruczeć/murceć 'mówić pod nosem’; pyskula o kobiecie kłócącej się, pyskującej (Młp pd-wsch, Ciesz) od pyskacz 'ts.'; pyszczula 'stale się wadząca z drugimi' (Młp pd) od pyszczyć 'pyskować'; skrzekula 'kobieta mówiąca przesadnie głośno' (Opol) od skrzeczeć 'krzyczeć'.

\section{Nazwy kobiet ze względu na charakterystyczną cechę}

3.1. Nazwy odnoszące się do wyglądu zewnętrznego: babrula 'kobieta /dziewczyna brudna, niechlujna' (Młp pd) od babrak 'człowiek, który się czymś brudzi, paprze'; brzydula 'brzydka kobieta, dziewczyna' (Młp, Ciesz, Opol), 'kobieta niechlujna, nieporządna' (Ciesz), 'o dziewczynce, która się ubłociła' (Młp pd-wsch) od brzydak 'człowiek brzydki, niechlujny, brudny'; bykula 'o dziewczynie wyrośniętej, silnej, niedbałej i leniwej' (Ciesz), 'o człowieku m i ż wysokiego wzrostu, nieco pochylonym' (Kasz) od byk przen. lub pogardliwie 'o człowieku (mężczyźnie albo wyrostku) silnym, zdrowym, leniwym, głupim, prymitywnym lub rozpustnym'; cycula 'kobie- 
ta o wydatnych piersiach' (Grn Śl, Opol) prawdopodobnie od cyc; czarnula 'kobieta o ciemnej cerze i czarnych włosach, brunetka' (ogólnopolskie) od czarny; dziadula 'o kobiecie źle, nieporządnie ubranej' (Młp pd, Ciesz), też pogardliwie o kobiecie (Opol) od dziad; dzidula 'wysoka szczupła kobieta' (Młp śr) od dzida 'wyrośnięta panna'; gajdula 'wysoka, długonoga dziewczyna' (Kasz) od gajdacz 'dryblas, drągal'; gizdula 'kobieta brudna, niechlujna' (Młp pd), 'kobieta bezwstydna' (Ciesz) od gizda/gizd 'człowiek brudny, niechlujny'; grajdula 'kobieta nieporządna, niedbała, brudna, nieumiejąca prowadzić gospodarstwa' (Młp pd) od grajda 'człowiek niedbały, powolny, ślamazarny'; gryndula 'kobieta brudna, niechlujna' (Młp pd, Opol) od gryndak 'człowiek niezgrabny, brudas, niechluj'; kordula 'dziewczyna nieumiejąca się ubrać; nieuczesana' (Młp pd) przezwisko od imienia Kordula; kosmula 'kobieta nieuczesana, rozczochrana' (Młp pn) od kosmacz 'mający włosy w nieładzie, rozczochrany'; krzywula 'przezwisko kobiety' (prawdopodobnie o skrzywionej sylwetce) (Młp pd) od krzywacz 'niedołęga' ze zmianą znaczenia; mazula 'ta, co się maże, brudzi' (Ciesz) od mazak 'brudas, mazgaj, niedołęga'; nosula 'kobieta $\mathrm{z}$ wielkim nosem' (Młp śr) od nosal 'człowiek z wielkim nosem'; paćkula 'dziewczyna lub kobieta tęga, mająca półkoliste policzki' (Młp pd) od paćkać 'dużo jeść'; papula m i ż 'człowiek mający pyzatą twarz; spuchnięty na twarzy' (Młp pd, Ciesz, Opol) od papa 'twarz'; piegula 'ta, co ma piegi' (Młp pd) od piegacz 'mężczyzna piegowaty'; pycula 'kobieta o pełnej piersi' (Opol) od niejasnej podstawy, prawdopodobnie jest to eufemizm wyrazu cycula; rzytula 'kobieta z dużym tyłkiem' (Grn Śl), 'kobieta lub dziewczyna dobrze upasiona, odchowana' (Młp wsch) od rzyton' 'człowiek z dużym tyłkiem'; szczerbula 'kobieta mająca braki w uzębieniu' (Młp pd, Śl pd-zach, Opol) od szczerbacz/szczerbak 'ts.'; wargula 'kobieta o dużych wargach' (Młp pd) od wargacz; zezula 'kobieta zezowata' (Młp pd-zach) od zez.

3.2. Nazwy odnoszące się do wieku i kondycji zdrowotnej: ajkula 'kobieta niemłoda, niezamężna' (Kasz) od niejasnej podstawy; babula 'kobieta, zwłaszcza stara' (Podl, Młp pd, Wlkp pn, Kasz) od baba 'stara kobieta'; cisula 'kobieta niedołężna, słaba' (Młp pd) od cisa prymarnie 'nazwa krowy koloru czerwonego lub żółtego'; dziewula 'młoda dziewczyna' (War-Maz, Podl, Wlkp pd, Kasz) od dziewka 'ts.'; kwękula 'kobieta, która kwęka, popłakuje' (Ciesz) od kwękać 'popłakiwać'; sikula 'młoda dziewczyna' (Młp śr) od sikoń 'młody chłopiec moczący się w nocy'; smarkula 'mała, niedojrzała dziewczyna' (ogólnopolskie) od smarkacz; starula 'stara kobieta lub dziewczyna' (Młp pd) od stary ; szczula 'młoda dziewczyna wychodząca $z$ lat dziecięcych, podlotek' (Opol) od szczoch 'o chłopcu ts.'; sznapula 'młoda dziewczyna' (Opol) od sznapa 'młody chłopak'; szpikula/śpikula 'dziewczyna smarkata, podlotek' (Młp pd-zach) od szpik/śpik 'młody chłopiec, smarkacz'; tryjdula 'stara kobieta, nieporządna' (Młp pd) od tryjdak 'wariat, biega tu i tu' ze zmianą znaczenia.

5 Starula to wyraz powszechnie nazywający maciorę, tylko w ok. Niepołomic nazwa ta została przeniesiona na kobietę. 
3.3. Nazwy odnoszące się do cech umysłu i charakteru: bajdula 'kobieta głupia, mało rozgarnięta, ograniczona umysłowo' (Młp pd) od bajdak 'człowiek mało rozgarnięty'; chytrula m i ż 'człowiek podstępny, przebiegły' (Kasz) od chytruk/chytrun 'ts.'; ciapula (m i ż) 'przezwisko człowieka niezdarnego' (Młp pd) od ciapa 'ts.; fifula (m i ż) 'mądrala, człowiek przebiegły' (Opol) od niejasnej podstawy; gizdula 'kobieta obrzydliwa, nieznośna' (Śl pd-zach) od gizda/gizd 'człowiek brudny, niechlujny’; głupiula 'dziewczyna głupia' (Młp pd-wsch) od głupi; głuptula 'głupia kobieta' (Młp pd-wsch) od głuptak; pazdrula 'kobieta skąpa, zachłanna, chciwa' (Młp pd) od pazdrak 'skąpiec, chciwiec, chytrus'; picula 'przezwisko kobiety skąpej' (Młp pd) od niejasnej podstawy; pizdula 'przezwisko kobiety skąpej' (Młp pd-wsch) od pizda 'wagina'; sycula 'o kobiecie skąpej' (Młp pd) od syc 'skąpiec'.

\section{Nazwy odnoszące się do zachowania (sposobu bycia):}

babrula 'kobieta niedorajda' (Młp pd) od babrak 'człowiek, który się czymś brudzi, paprze'; chamrula 'o kobiecie guzdrała' (Opol) od chamrot; chichrula 'dziewczyna skłonna do śmiechu' (Opol) od chichrot; chłopczula 'dziewczyna o żywym temperamencie, lubiąca męskie towarzystwo' też 'dziewczyna lekkich obyczajów’ (Śl pn) od chłopiec; chłopula 'dziewczyna lekkich obyczajów' (Śl pn) też 'dziewczyna lubująca się w zajęciach męskich’ (Kasz) od chłop; cyfrula 'kobieta, która ładnie tańczy’ (Młp pd) od cyfrować 'tańczyć cyfrowanego (rodzaj tańca góralskiego)'; drzykula 'o małej dziewczynce, która rozrabia i psoci' (Ciesz) od drzyk 'mały chłopiec, który psoci'; drzystula 'o kobiecie, która wypuszcza gazy z kiszki odbytowej' (Ciesz) od drzystoń 'o mężczyźnie ts.'; fajnula 'dziewczyna przebierająca w partnerach na zabawie', 'osoba przesadnie zadbana, strojnisia' (Ciesz) prawdopodobnie od niem. fein 'delikatny'; fyrtula 'o kobiecie szybko chodzącej z miejsca w miejsce' (Ciesz) od fyrtak 'człowiek prędki'; gońcula 'o dziewczynie, która się włóczy, lubi towarzystwo mężczyzn' (Opol) od goniec 'mężczyzna lekkich obyczajów'; gzicula przezwisko (w kartotece bez objaśnienia znaczenia) (Młp pd) prawdopodobnie od gzica 'kobieta latawica'; kotula 'dziewczyna latająca za mężczyznami, kociak' też 'dziewczyna zaniedbana' (Opol) od kot; lizula 'dziewczyna, która się podchlebia' też 'dziewczyna próżna' (Opol) od lizak 'lizus, pochlebca'; łakomcula 'kobieta chciwa, łakoma' (Młp pd) od łakomiec 'ts.'; myrzula 'młoda pełna energii i chęci do zabaw dziewczyna' (Śląsk pd-zach) od myrzak 'o człowieku: figlarz, młody, pełen energii'; paprula 'kobieta niechlujnie robiąca' (Młp pd) od paprak 'wykonujący niedbale robotę'; płaczkula 'płaczka, kobieta często płacząca' (Młp pd, Opol) od płaczek; prostula 'prosta kobieta bez „pańskich” manier' (Wlkp śr) od prostak; rżula 'dziewczyna lubiąca się dużo śmiać' (Opol) od rżeć 'śmiać się’; skrabula 'o kobiecie, która wciąż się drapie' (Młp pd) od skrabać się 'drapać; słowikula 'kobieta lekkich obyczajów' (Opol) od słowik 'ptak' ze zmianą znaczenia; smykula 'latawica, dziewczyna lubiąca mężczyzn' (Ciesz, Opol), 'kobie- 
ta lekkich obyczajów' (Opol) od smyka 'kobieta lekkich obyczajów'; srajdula 'osoba zanieczyszczająca się własnymi odchodami; młokos, smarkacz, podlotek' (Kasz) od srajda 'ts.'; srajwula 'kobieta niedbała, plucha' (Młp śr) od niejasnej podstawy; ślimtula 'o dziewczynie: beksa; dziewczyna wciąż płacząca' (Śl pd-zach) od ślimtacz 'o mężczyźnie: beksa'; szmajdula 'kobieta mańkut' (Młp pn) od szmajda 'mańkut'; śmiechula 'dziewczyna lubiąca się dużo śmiać' (Opol) od śmiech; śmiejula 'dziewczyna lubiąca się dużo śmiać' (Opol) od śmieja 'człowiek lubiący żartować, śmiać się;; świętula 'świętoszka' (Młp pd) od święty; zębula 'dziewczyna lubiąca się dużo śmiać (Opol) od zębacz 'ten, który się ciągle śmieje’; zwyrtula 'kobieta niedokładna w pracy' (Młp pd) od zwyrtak 'taki, co niedokładnie robi'.

\section{Nazwy przezwiskowe:}

nacechowane ujemnie: ceprula 'mieszkanka nizin' (Młp pd) od ceper 'ts.'; jędzula 'zdrobnienie' (Młp wsch) od jędza; strzygula 'przezwisko obelżywe; czarownica' (Młp pd) od strzyga; wydrula 'przezwisko obelżywe' (Młp pd) od wydra. Z nacechowaniem dodatnim (pieszczotliwe): wdowula 'zdrobniale wdowa' (Maz) od wdowa; Żydula 'Żydówka, najczęściej młoda i ładna' (Młp pd, Śl pd-zach) od Żyd.

W indeksie a tergo do kartoteki SGP PAN zanotowano 446 wyrazów zakończonych na -ula. W grupie tej 138 wyrazów to derywaty będące nazwami kobiet. Jeśli weźmiemy pod uwagę, że w Indeksie alfabetycznym wyrazów z kartoteki „Słownika gwar polskich" (Reichan 1999) zamieszczono 240 ooo jednostek, to przedstawiony tu zbiór stanowi niecałe sześć setnych procenta całości. Ale i tak produktywność sufiksu -ula w gwarach w stosunku do języka ogólnopolskiego jest 8 razy większa (138 nazw w gwarach, 17 w SJPD). Ponad połowa derywatów (79) to derywaty modyfikacyjne powstałe od nazw męskich, np. bajczula od bajczarz, chlaptula od chlaptacz, drzystula od drzystak. Te z kolei są derywowane przeważnie od czasowników, często odonomatopeicznych, najczęściej za pomocą sufiksów -acz (gw. -oc) oraz -ak (gw. -ok), inne sufiksy są mniej liczne. 20 formacji z sufiksem -ula powstało od rzeczowników niebędących nazwami męskimi. O takiej pochodności wyrazów świadczy brak w kartotece odpowiednich nazw męskich. $12 \mathrm{z}$ nich utworzono od innych nazw żeńskich, np. smykula od smyka, wydrula od wydra. 19 formacji powstało od czasowników, z których większość to czasowniki odonomatopeiczne. 6 formacji powstało od przymiotników, pozostałe są niejasne.

Zasięg sufiksu -ula tworzącego apelatywne nazwy kobiet zasadniczo pokrywa się z wyznaczonym przez A. Zarębę (1965) zasięgiem sufiksu -ula używanego w funkcji tworzenia nazw żon od nazwisk mężów. W tej funkcji sufiks „,występuje w południowo-zachodnich dialektach polskich, mianowicie na Podhalu i w jego sąsiedztwie, na znacznym obszarze Śląska południowego i południowo-zachodniego: w Cieszyńskiem, Bielskiem, Rybnickiem, Kozielskiem, Raciborskiem, Głubczyckiem, Prudnic- 
kiem, sięgając pod Gliwice, a nawet pod Częstochowę" (ibid.: 457). W apelatywach zasięg jest nieco szerszy, jednostkowe przykłady kartoteka SGP PAN notuje w Lubelskiem, nieco więcej w Rzeszowskiem, zdecydowanie najwięcej na południu, w tym z największą frekwencją w powiecie limanowskim (Mszana Dolna i Górna ok. 50 formacji $)^{6}$, kilkanaście wyrazów pochodzi ze Śląska Cieszyńskiego i Śląska południowo-zachodniego. Formacje z tym sufiksem są obecne na Opolszczyźnie, jednostkowe przykłady pochodzą z Wielkopolski i Mazowsza, bardzo niewiele pochodzi z terenu Kaszub.

Co do funkcji znaczeniowych sufiksu -ula, to wydaje się, iż najpełniejszy obraz przedstawił S. Warchoł (1968: 57). Stwierdził mianowicie, że formacja ta pełni przede wszystkim funkcję ekspresywną (o charakterze pejoratywnym), tworzy nazwy żon od nazwisk mężów i nazwiska córek od nazwisk ojców oraz liczne, szczególnie w Małopolsce, nazwy krów. Warta podkreślenia jest tu funkcja ekspresywna, pojawia się ona bowiem w pracach innych badaczy. Na przykład A. Kowalska (1982: 75) stwierdza, iż w gwarach sufiks ten tworzy „zarówno deminutiva i hypokoristica, jak i formacje o zabarwieniu pejoratywnym”. Józefa Kobylińska (2003: 217) z kolei, pisząc o nazwach kobiet w gwarze zagórzańskiej, formacje z sufiksem -ula zalicza do grupy nazw pejoratywnych będących derywatami. Według A. Zaręby (1965: 461) formant - ula ma dwa znaczenia: 1) ogólnie feminizujące (z zabarwieniem zdrabniającym), 2) określające żony (od nazwiska, przydomka, imienia czy zawodu męża). Z tych dwu znaczeń to pierwsze, ogólniejsze jest pierwotne, drugie jest zawężone do jednej kategorii. Franciszek Sławski (1974: 110) pisał o funkcji ekspresywnej i feminizującej tego formantu. Jeśli idzie o znaczenie sufiksu -ula w odapelatywnych nazwach kobiet, to trzeba stwierdzić, iż w zdecydowanej większości omówionych formacji formant pełni funkcję feminizującą, tworzy nazwy żeńskie od istniejących już i najczęściej derywowanych nazw męskich. Podstawy, od których powstają te formacje, już są nacechowane ekspresywnie (głównie są to pejoratywa), np. ciamkacz, paćkarz, paprak, srajda. Sufiks -ula nie wnosi więc do tworzonej nazwy negatywnego odcienia znaczeniowego, bo taki zawiera się już w niej samej, np. ciamkula, paćkula, paprula, srajdula. Sufiks, co najwyżej, jak zauważa Stanisław Grabias (1981: 70) - może „potęgować pejoratywność. Ekspresywność formacji nie musi wynikać z „udziału formantów w procesie ekspresji” (ibid.: 43). W wielu wyrazach uznanych za ekspresywne nacechowanie jest skutkiem przeniesienia „wartości emocjonalnej z wyrazu podstawowego na pochodny" (ibid.). I taki proces jest widoczny w omówionym materiale. Podstawy niebędące nazwami męskimi też są nacechowane. $Z$ pozoru mogą się wydawać neutralne, np. dzidula od dzida, wydrula od wydra, ale jeśli uwzględnimy fakt, że oba te wyrazy zostały przeniesione na określenia ludzi o pewnych

6 Warto tu zauważyć, że występowanie tego sufiksu nie jest równomierne. W Słowniku gwary gorczańskiej (zagórzańskiej) Józefa Kobylińska (2001) zanotowała ponad 30 nazw kobiet, w niedalekiej Sidzinie i Więciórce Marian Kucała nie zanotował żadnej (Kucała 1957). 
cechach fizycznych bądź charakteru, to to nacechowanie zostanie przeniesione do kolejnych formacji, w omawianym przypadku do formacji żeńskiej z sufiksem -ula. Podobnie rzecz się ma, gdy podstawami są czasowniki - jest ich w naszym materiale 19, wszystkie są nacechowane ujemnie i to nacechowanie przeszło do pochodnych od nich nazw kobiet. Funkcję ekspresywną związaną, jak wiadomo, z emocjami nadawcy sufiks -ula pełni w imionach żeńskich powstałych od form podstawowych tych imion, np.: Wandula od Wanda, Anula od Anna, Danula od Danuta. Powstają formacje hipokorystyczne, które sygnalizują sympatię nadawcy. Niektóre formacje są tworzone już od zdrobniałych podstaw, np.: Basiula od Basia, Kasiula od Kasia, Kaziula od Kazia. Sufiks -ula wnosi więc do derywatu dodatkowy odcień pieszczotliwości. W nazwach żon od nazw mężów czy w nazwach córek od nazwisk ojców, niezależnie, czy podstawy są nacechowane, czy są neutralne, sufiks pełni funkcję feminizującą, ekspresywność danej nazwy wynika z nacechowania podstawy.

Jak można było zauważyć, zdecydowana większość omówionych wyrazów jest nacechowana negatywnie. Nie ma w tym nic zaskakującego, wiemy bowiem z badań Elżbiety Laskowskiej (1993), że w języku potocznym przeważa wartościowanie negatywne. W gwarze, która według wielu badaczy, ze względu choćby na mówioność, charakteryzuje się większą ekspresywnością niż język ogólny, jest podobnie (Karaś 2010). Dominację określeń negujących wśród pochodzących z Orawy gwarowych ekspresywnych nazw człowieka, zwłaszcza odnoszących się do jego cech fizycznych i charakterologicznych, zauważył Józef Kąś (1994: 121). Badając słownictwo pochodzące $z$ dawnej Litwy należące do tego samego pola leksykalnego, notowane przez Jana Karłowicza w jego słowniku (SKarł), Elżbieta Koniusz (2001: 143) zauważyła „przewagę nazw cech ujemnych, zawierających silny ładunek emocjonalny”. Te przykładowe spostrzeżenia wskazują wyraźnie na konieczność podjęcia szerszych badań nad udziałem negatywnych ocen w gwarach.

\section{Skróty}

Ciesz - Śląsk Cieszyński; Grn Śl - Górny Śląsk; gw. - gwarowy; Kasz - Kaszuby; Maz - Mazowsze; Młp - Małopolska: pd - południowa, pd-wsch - południowo-wschodnia, pd-zach południowo-zachodnia, pn - północna, pn-zach - północno-zachodnia, śr - środkowa, wsch - wschodnia; niem. - niemiecki; Opol - Śląsk Opolski; Podl - Podlasie; Śl - Śląsk: pd-zach - południowo-zachodni, pn - północny; War-Maz - Warmia i Mazury; Wlkp Wielkopolska: pd - południowa, pn - północna, śr - środkowa 


\section{Literatura}

Cyran W., 1977, Tendencje słowotwórcze w gwarach polskich, Łódź.

Doroszewski W., 1929, Monografie słowotwórcze II. Formacje z podstawowym -1 w części sufiksalnej, „Prace Filologiczne” XIV, s. 81-82.

Grabias S., 1981, O ekspresywności języka. Ekspresja a słowotwórstwo, Lublin.

Grzegorczykowa R., Puzynina J., 1979, Słowotwórstwo współczesnego języka polskiego. Rzeczowniki sufiksalne rodzime, Warszawa.

Grzegorczykowa R., Puzynina J., 1984, Słowotwórstwo rzeczowników, [w:] R. Grzegorczykowa, R. Laskowski, H. Wróbel (red.), Gramatyka współczesnego języka polskiego. Morfologia, Warszawa, s. 332-407.

JANIGA M., 2016, Ekspresywne nazwy osób w Słowniku gwar polskich Jana Karłowicza, [w:] D.K. Rembiszewska (red.), Słowiańskie słowniki gwarowe tradycja i nowatorstwo, Warszawa - Łomża, s. 83-94.

Karaś H. (red.), 2010, Dialekty i gwary polskie. Kompendium internetowe, www.dialektologia.uw.edu.pl/index.php (dostęp: 14 X 2020).

Kąś J., 1994, Kulturowy stereotyp mężczyzny i kobiety w środowisku wiejskim (na materiale gwar orawskich), [w:] J. Anusiewicz, K. Handke (red.), Płeć w języku i kulturze, „Język a Kultura", t. 9, Wrocław, s. 119-130.

KobylińsKa J., 2001, Słownik gwary gorczańskiej (zagórzańskiej), Kraków.

Kobylińska J., 2003, Żeńskie nazwy pejoratywne w gwarze gorczańskiej, [w:] U. Sokólska, P. Wróblewski (red.), Słowa jak mosty nad wiekami, Białystok, s. 215-225.

Koniusz E., 2001, Polszczyzna $z$ historycznej Litwy w Słowniku gwar polskich Jana Karłowicza, Kielce.

Kowalska A., 1982, Formacje z sufiksem -ula w gwarach polskich, „Studia Linguistica Polono-Jugoslavica" II, s. 69-72.

KREJA B., 1964, Słowotwórstwo nazw żeńskich we współczesnym języku polskim, „Język Polski” XLIV, s. 129-140.

KuCAŁA M., 1957, Porównawczy słowik trzech wsi małopolskich, Wrocław.

KUCHARZYK R., 2015, „Słownik gwar polskich” PAN - nowe możliwości, nowe wyzwania, „Rozprawy Komisji Językowej Łódzkiego Towarzystwa Naukowego” LXII, s. 163-173.

LAsKowsKa E., 1993, Wartościowanie w jezzku potocznym, Bydgoszcz.

MasŁowsKa E., 1980, Słowotwórcze typy pejoratywnych nazw osób w dialekcie kaszubskim „Studia z Filologii Polskiej i Słowiańskiej” XIX, s. 41-58.

Piechniк A., 2009, Wizerunek kobiety i mężczyzny w językowym obrazie świata ludności wiejskiej (na przykładzie gminy Zakliczyn nad Dunajcem), Kraków.

ReICHAN J. (red.), 1999, Indeks alfabetyczny wyrazów z kartoteki „Słownika gwar polskich”, t. 1: $A-O$, t. 2: $P-\dot{Z}$, Kraków.

SGP PAN: Słownik gwar polskich, red. M. Karaś (Źródła, t. 1), J. Reichan (t. 2-9, z. 2), S. Urbańczyk (t. 2-5), J. Okoniowa (t. 6-9, z. 2), B. Grabka (t. 7-9, z. 2), R. Kucharzyk (t. 9, z. 2t. 10, z. 2), t. 1-3: Wrocław - Warszawa - Kraków 1977-1991, t. 4-10: Kraków 1992-2019.

SJP XVII-XVIII: W. Gruszczyński (red.), Elektroniczny słownik języka polskiego XVII i XVIII wieku, [on-line:] https:/SXVII.pl.

SJPD: W. Doroszewski (red.), Słownik języka polskiego, t. I-XI, Warszawa 1958-1969.

SKARŁ: J. Karłowicz, Słownik gwar polskich, t. I-VI (t. IV-VI do druku przygot. J. Łoś), Kraków 1900-1911. 
SL: S.B. Linde, Słownik języka polskiego, t. I-VI, Lwów 1854-186o.

SŁAWSKI F., 1974, Zarys słowotwórstwa prasłowiańskiego, [w:] idem, Słownik prasłowiański, t. 1, Wrocław, s. 43-141.

SPXVI: Słownik polszczyzny XVI wieku, t. I-IV, red. komitet redakcyjny, t. V-XVII, red. M.R. Mayenowa, t. XVIII-XXXIV, red. F. Pepłowski, t. XXXV-XXXVI, red. K. Mrowcewicz, P. Potoniec, Wrocław - Warszawa - Kraków 1966-2012.

SSTP: S. Urbańczyk (red.), Słownik staropolski, t. I-XI, Warszawa 1953-2002.

WARCHOє S., 1968, W sprawie genezy i funkcji sufiksu -ula $w$ słowiańskich nazwach osobowych $i$ apelatywach, "Z Polskich Studiów Slawistycznych”, seria 3, „Językoznawstwo”, s. $55-63$.

ZARęBA A., 1965, Ze związków językowych polsko-czesko-słowackich (rodzimy przyrostek -ula), „Studia z Filologii Polskiej i Słowiańskiej” V, s. 457-464.

\section{Dialectal Female Names with the Suffix -ula Summary}

The article discusses female names created with the suffix -ula, taken from the Lexicon of Polish Dialects prepared by the Polish Institute of Sciences (PAN). Despite the possibility of double motivation, it was assumed that most of them were motivated by male names, with only few derived from verbs, adjectives or nouns. Among the formations in question, words with a negative connotation are prevalent, and positive ones (diminutives and terms of endearment) are rare. This is compliant with colloquial Polish in which negative assessment is dominant, too. According to the analysis: 1) the suffix - ula has a feminizing function when it is used to create female names based on common names, and the expressiveness of the name is transferred from the basis to the derivative; 2 ) the scope of the suffix -ula is limited to Lesser Poland and Silesia; 3 ) it hardly ever occurs in other dialects. 